日醖外医会誌 $53(6), 1261-1264,1992$

原蓄

超音波スクリーニングにて発見された甲状腺癌の検討

\author{
山梨県厚生連健康管理センター \\ 河野浩二小河原忠彦小林一久 \\ 山梨医大第 1 外科 \\ 関川敬義山本正之松本由朗
}

甲状腺矤患の診断においては，超音波険㚗はその重要な位㯰を占めている.当センター では, 人間ドックに打ける多烚器超音波検查の一つとして, 甲状腺超音波スクリーニン グを実施し，21.471人の対象の中から15例（発見率0.07\%）の甲状腺癌を発見した。10

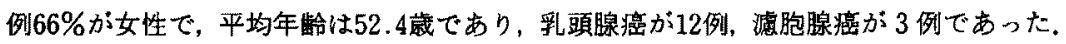
微小癌が 2 例発見されている一方, リンパ節転移 $\mathrm{n} 1(+) か ゙ ~ 4$ 例, 腺外漫潤 ex (十)が 3 例に認められている，超音波所見では，モザイクェコー11例，低ェコー4例で，この らち strong echoをともならすのは11例をしめた，また，触診上不触知（JTO）で，超 音波のみでスクリーニングできた症例が 2 例認められた。甲状腺超音波スクリーニンク は, 発見率, 診断能, 簡便性などの面から有効と考えられた。

索引用語：甲状腺癌，超音波スクリーニング

はじめに

甲状腺疾患の診断にお゙ける超音波検査は，その画像

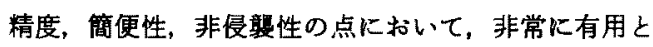
されている122．当センターでは，人間ドックにおける 多搭器超音波険診の対象藏器の一つとして甲状腺を取 り入九，甲状腺疾患，とりわけ，甲状腺澏の早期発見 に努めている。令回，超音波スクリーニングにて発見 された甲状腺癌につき検討を加えたので報告する。

\section{対象と方法}

対象 1 ：当センターに打ける人間ドックにて, 1986 年 6 月から1990年12月までに甲状腺超音波スクリーニ ングを実施した14,351人（豕年検診者を加え，延べ 21,471人)を対象とし，主に発見甲状腺癌について険 討した。男性7.552人，女性6.799人で，受診者の年龄 分布は図 1 のことくであり，40歳代から60歳代が多く， 受診者全体の $88 \%$ を占めた。

対象 2 ：势音波所見をさらに詳しく検討する目的 で,同様に1990年12月～1991年 5 月に実施した2,909人 を対象として，超音波所見，触猃所見，精査結果につ いて検討した。

機種はフロカSSD-650電子スキャン，挆触子はイン

1991年 8 月 8 日受付 1992年 3 月25日採用
ラインスキャナ ASU-32WL 7.5MHz 及び10MHz 用い，頸部伸展位にて䌅断像，横断像を観察した。検 查は主に敬床検查技師が行い，医師が読影、診断を行っ た。

要精検とすべき超音波所見としては，充実性瘇瘤像 (高ェコー，低ェコー，モザイク状)，多発性索包像，

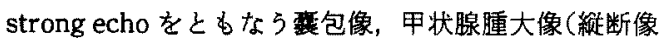
における厚さ $15 \mathrm{~mm}$ 以上）の項目を基準とした。

精査は当センター及び他医療機関に依頼して実施し た.

\section{結 果}

対象 1：全受診者の5ちで要精検者は644例(要精娭 率3.0\%)であり，この中から15例の甲状腺癌が発見さ れている(発見率 $0.07 \%=15$ 人 $/ 21,471$ 人)。この5ち， 10例66\%が女性で，平均年龄は52.4藏であった，1例 は甲状腺癌の再発症例であり，残りの14例につき検討 を加えた（表 1)，腫瘤を自覚していた症例はなく，触 診上，不触知（JTO）すなわち，超音波検亘のみでス クリーニングできた症例が 2 例認められた。エコー上 腫瘍最大径は最大 $26 \mathrm{~mm}$ ，最小 $7 \mathrm{~mm}$ で，内部ェコー所 見は，モサイク10例，低ェコー4例でありここのち strong echoをとむならすのは11例（このらち軟線撮 影比て石灰化を認めた。のは8例）をしめ，甲状腺癌 


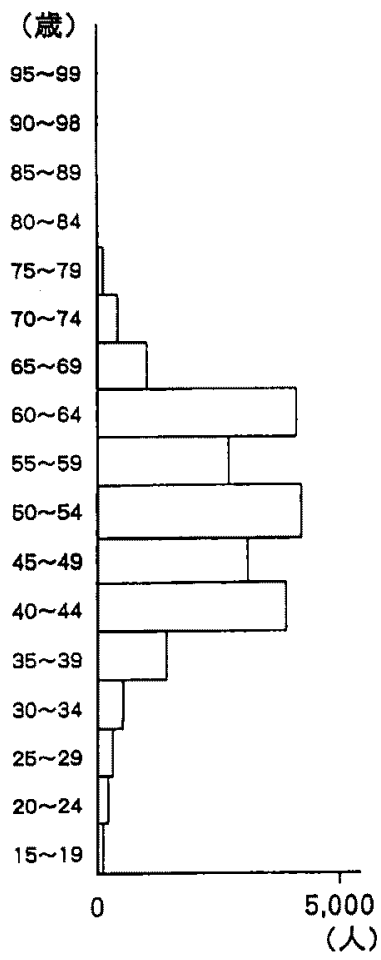

図 1 超音波検㚗受暗者数

の診断上重要な所見と考えられた，反对に，strong echoを伴わない癌も 3 例認められている. 超音波発見
甲状腺湂のらら，頙部軟線撮影では石灰化が認められ なかったものが6例（43\%）方り，軟線撮影による検 出率は不十分と考之られた。ま，13例に術前の吸引 細胞診が実施され，9例に class $\mathrm{V}$ の確診が得られて いる。

全例に甲状腺癌の術前診断のもと，手術が実施され， 組織学的には11例が papillary carcinoma， 3 例が follicular carcinomaであった。微小癌が 2 例発見されて いる一方，4 例が nl (十)，3 例が ex1の所見となり， 必ずしも限局した瘦とは限らなかった。な格，全症例 とす現在まで生存している。

症例11につき呈示する(図 2，图 3).49藏女性，1990 年12月，人間ドックの甲状腚超音波検查にて，右葉に 径10mmのモザイク状腫瘤を認めた。 strong echoを 伴い，腫瘤は表面に突出していることから悪性を強く 疑い，吸引細胞診を実施したところ， class V が得られ た。

对象 2：該当期間における2,909人の5ち，要精検者 は130人（要精検率4.6\%) で，超音波所見は表 2 のご とくである。このらち当センターにて精查を行った 73 人を検討すると，超音波検査上結節性病変として認め られた56例中，触診上，触知可能であったのは25例 （45\%）であった，貨部軟線撮影，CT，核医学検査， 血液学的検查を症例により追加し，35例に対し超音波 ガイト下に吸引細胞診を実施した。このらち1例保甲 状腺癌の確定診断 (class V)が得られて扣り，class IV が 1 例, class III が 3 例, class II が 7 例とい5結果と

表 1 超音波検査で発見された甲状腺插症例

\begin{tabular}{|c|c|c|c|c|c|c|c|c|c|c|c|c|c|}
\hline \multicolumn{14}{|c|}{ 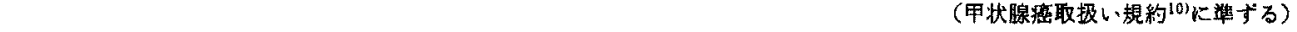 } \\
\hline No. & 鿊列 & 年路・性 & 触酸 & 部位 & $\begin{array}{c}\text { 大㤩 } \\
\text { 㻴大往 }(\mathrm{mm})\end{array}$ & $\begin{array}{l}\text { 睡㾇内部 } \\
エ \text { 界見 }\end{array}$ & $\begin{array}{l}\text { Strong } \\
\text { Echo }\end{array}$ & $\begin{array}{l}\text { 㨁線 } x-p \\
\text { 名化 }\end{array}$ & $\mathrm{ABC}$ & \multicolumn{4}{|c|}{ 術後病理診断 } \\
\hline 1. & K. K. & $52 \cdot 女$ & JT 1 & 左筮 & 15 & モザイク & + & + & $\mathrm{V}$ & pap & t 4 & n 1 & ex 1 \\
\hline 2. & S.H. & $50 \cdot 女$ & JT 1 & 左架 & 13 & 低 & + & + & $\mathrm{V}$ & pap & $t 1$ & n 1 & \\
\hline 3. & T.H. & 46・男 & $\mathrm{JT} 2$ & 左葉 & 23 & モザイク & - & - & $\mathrm{V}$ & foll & $t 2$ & n 0 & \\
\hline 4. & M.E. & $42 \cdot 女$ & JT 1 & 有葉 & 13 & 低 & - & - & $\mathrm{V}$ & pap & t 1 & n 0 & \\
\hline 5. & T.H. & $66 \cdot 女$ & JT 1 & 左賲 & 15 & キザイク & + & + & V & pap & 1 & no & \\
\hline 6. & N.S. & 53 - 舁 & $\mathrm{JT} 1$ & 左集 & 19 & モザイク & + & - & V & foll & t 4 & n 0 & ex 1 \\
\hline 7. & K.S. & $44 \cdot 女$ & JT 0 & 左集 & 7 & 低 & - & - & $\mathrm{V}$ & pap & tis & no & \\
\hline 8. & $Y . I$. & 42・男 & JT 1 & 右集 & 16 & ヒザイク & + & + & IV & pap & $\mathbf{t} 1$ & n 0 & \\
\hline 9. & K. H. & $56 \cdot$ 女 & JT 1 & 右葉 & 26 & 低 & + & + & $\mathrm{V}$ & pap & $t 2$ & n 0 & \\
\hline 10. & Y.A. & 61・男 & $\mathrm{JT} 1$ & 左藮 & 17 & モザイク & + & + & $\mathrm{V}$ & pap & t 1 & n 0 & \\
\hline 11. & C. Y. & $49 \cdot 女$ & JT 1 & 右藮 & 10 & モザイク & + & + & $\mathrm{V}$ & pap & t 1 & n 1 & \\
\hline 12. & S. K. & $58 \cdot$ 女 & $\operatorname{JT} 0$ & 右葉 & 8 & モザイク & + & - & III & foll & tis & no & \\
\hline 13. & N.T. & 47 ·男 & JT 1 & 右潅 & 15 & モザイク & + & + & - & pap & $t 4$ & $\mathrm{n} I$ & ex 1 \\
\hline 14. & K. M. & $51 \cdot 女$ & JT 1 & 左集 & 13 & モザイク & + & - & IV & pap & t 1 & no & \\
\hline
\end{tabular}

pap = papillary carcinoma foll=follicular carcinoma

$\mathrm{ABC}=$ Aspiration biopsy cytology 


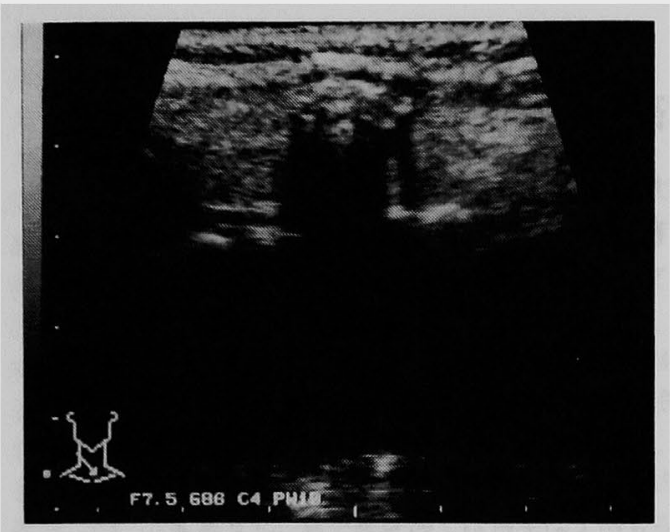

図2 症例11の超音波検査所見

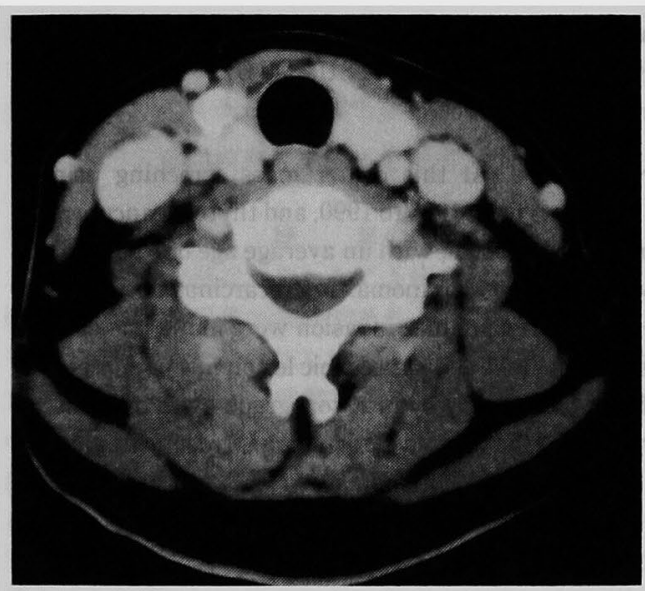

図 3 症例11の CT 検查所見

なっている、また，同対象73例中，甲状腺腫大像及び 全体不均一像より，慢性甲状腺炎を疑ったるのが13例 あり，このうち，抗ミクロゾーム抗体陽性10例，抗サ イロイド抗体陽性 4 例が認められ，このうち 2 例には 甲状腺機能低下症（いずれる無症状）があった。

\section{考察}

1）甲状腺癌の発見率について

従来，甲状腺癌の集団検診は，主に成人女性に対す る視触診として行われてきだ!。最近は，超音波スク リーニンクによる報告もいくつかあり，その発見率は， 小俣ら4は，男性0.22\%，女性0.69\%，斉藤古は0.5\%と 報告しており，視触診のみのスクリーニングに比べ有 効であるとしている，特に，超音波検查によって得ら れる情報は多く，スクリーニングと同時に，かなりの

\section{衰 2 超音波所見}

\begin{tabular}{lr} 
& ( $\mathrm{n}=130)$ \\
\hline Hyperechoic mass & 6 \\
Isoechoic mass & 16 \\
Hypoechoic mass & 47 \\
Mosaicecho mass & 48 \\
Diffuse swelling (no mass) & 13 \\
\hline
\end{tabular}

$\cdot 90.12 \sim \cdot 91.5$

質的診断が得られる．触知困難な $10 \mathrm{~mm}$ 以下の微小癌 についてもその発見は可能と考えられ6)，横沢》は徽小 癌の超音波検査に拈ける正診率72\%を報告している。 また，触診には，ある程度の熟練を要し，かつ主観的 要素をとむなうが，超音波検查による診断は比較的容 易であり，客観的評価が可能である.

\section{2) 発見例の臨床的検討}

一般に，甲状腺癌の大部分は增殖速度の緩やかな分 化癌でありその予後は良好とされている，また，剖検 例の報告では，潜在性の甲状腺癌がかなりの高率で存 在することも知られており，高橋》は $13.8 \%$, Sweden では Bondeson ら"が $7 \%$ と報告している.このこと より，超音波集団検診による発見がその予後の向上に 影響するか否かは疑問視する意見もあり，今後の長期 生存率などの検討を待たざるをえない，しかし，今回 のわれわれの検討においては，発見時すでに腺外漫潤 やリンパ節転移を認める症例があり，明らかに，検診 による発見が予後の向上に重要な位置を占めていると 考えられる，また，触診では発見されにくい微小甲状 腺癌についても, 伊藤"9)報告のように, 最大径 $0.5 \mathrm{~cm}$ 以上については既に個体を㓏かす癌で，症例によって は既にリンハ、節転移を伴うむのもあり，その早期発見 につとめるべきであるとしている，今後，さらに症例 を重ねて，早期発見と臨床的意義との関係を明らかに していきたい.

$$
\text { おわりに }
$$

超音波スクリーニンクにより発見された甲状腺癌 (発見率0.07\%)について検討し，その有効性について 若干の考察を加えて報告した。

\section{文献}

1）横沢 保：甲状腺癌の診断之治療，この診断法で どこまでわかるか一超音波検查，臨外 41：545 $-551,1986$

2) Simeone JE, Daniels GH, Mueller PR, et al : High-resolution real-time sonography of the thyroid. Radiology 145: 431-435, 1982 
3）野口昌邦，北林一男，山田洋己他：集検で発見され た甲状腺癌症例の検討，内分泌外科 $2: 231-236$, 1985

4）小俣好作，望月敬司，千野正彦他：超音波検查によ

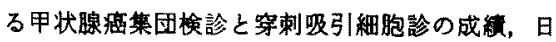
臨細胞会誌 $24: 680-685,1985$

5）斉藤守広：腹部超音波検查時の甲状腺スクリー二 ングについて，日超音波医会 $18: 262-268,1991$

6) 張 裕泰，即田太：甲状腺微小癌の超音波画像 と病理所見の比較検討，超音波医 $16: 471-476$, 1989
7) 高㰌信二：潜在性甲状腺踏の臨床病理学的研究, 日内分泌会誌 $45: 65-79,1968$

8) Bondeson L: Occult papillary thyroid carcinoma in the young and the aged. Cancer 53 : 1790-1972, 1984

9）伊藤国彦：第 1 回内分泌外科クリニカルカンフナ ランス甲状腺小癌をめぐって，内分渓外科 1 : 52,1984

10）甲状腺外科検討会編：甲状腺瘦取扱い規約（第 3 版)，金原出版， 1988

\title{
THYROID CANCERS DETECTED BY THE MASS SCREENING USING ULTRASONOGRAPHY
}

\author{
Koji KONO, Takahiko OGAWARA and Kazuhisa KOBAYASHI \\ Yamanashi Kouseiren Health Care Center \\ Takayoshi SEKIKAWA, Masayuki YAMAMOTO and Yoshirou MATSUMOTO \\ First Department of Surgery, Yamanashi Medical College
}

Ultrasonography ranks high in the diagnosis of thyroid disease. At this center mass screening using ultrasonography of the thyroid gland was performed in 21,471 subjects from 1986 to 1990 , and thyroid cancer was found in 15 of them (detective rate: $0.07 \%$ ). The male-to-female ratio was 10:5, with an average age of 52.4 years. There were 12 patients with papillary carcinoma and 3 with follicular carcinoma. Microcarcinoma could be detected in 2 patients, however, lymph node metastasis $\mathrm{nl}(t)$ and extraglandular invasion were found in 4 and 3 patients respectively. Ultrasonographic findings included mosaic echo in 11 and hypoechoic lesion in 4 patients. Of the 15 patients 11 were associated with strong echo. Successful diagnosis only by ultrasonography was made in 2 patients whose lesions were not palpable (JTO). The mass screening of the thyroid gland using ultrasonography is available in terms of its detective rate, good diagnosis ability, and easiness in handling. 